http://jmscr.igmpublication.org/home/ ISSN (e)-2347-176x ISSN (p) 2455-0450

crossref DOI: https://dx.doi.org/10.18535/jmscr/v8i3.107

\author{
Journal Of Medical Science And Clinical Research

\title{
Evaluation of fibrinogen level as a non conventional risk factor in patients of acute MI in north Indian patients
}

\section{Authors \\ Dr Rajkumar Verma, Dr Mridul Chaturvedi, Dr Sachu Sabu, Dr Kushal Pal}

\section{Introduction}

The conventional risk factors, like age, smoking, hyperlipidaemia do not explain all the mortality and morbidity due to coronary artery disease ${ }^{[1]}$. Recently non-conventional factors like plasma fibrinogen, $\mathrm{C}$ reactive protein, homocysteine have been recognized as independent risk factors to explain the present epidemic of coronary artery disease in Indian patients. ${ }^{[2]}$ Serum fibrinogen is a newer independent risk factor for $\mathrm{CAD}^{[3]}$. Fibrinogen increases the blood viscosity and plays a key role in thrombosis, both of which promotes coronary artery atherosclerosis.

In cardiovascular disease, fibrinogen has been mainly considered as being involved in thrombotic occlusion and hence in the final stage of atherosclerosis ${ }^{[5]}$. Fibrinogen is a well-known acute phase protein and the most abundant coagulation factor in the blood. As a short half-life protein and indicator of procoagulant state which was swiftly consumptions, circulating Fib was not only involved in acute phase of acute coronary syndrome (ACS) but also participated in chronic inflammatory response, which could accelerate the progress of atherosclerosis, and subsequently lead to the development of clinical CAD. ${ }^{[6]}$

Experimental studies have also suggested that fibrinogen and fibrin degradation products may increase coronary plaque vulnerability by stimulating coagulation, platelet aggregation, and vascular endothelial dysfunction. ${ }^{[7]}$ However a number of investigators have suggested that fibrinogen may play a more active role in the development and progression of atherosclerotic plaque. ${ }^{[8]}$ Smooth muscle cell proliferation stimulated by fibrinogen, suggests that fibrinogen is involved in the earliest stage of plaque formation. ${ }^{\text {[9] }}$

\section{Material and Methods}

Present study was done in 50 patients of acute MI admitted to the Medicine Department and Cardiology Department of S.N. medical college, Agra. Sample comprised of 50 cases and 10 cases as control. Patients complaining of chest pain lasting more than 30 minutes and fulfilling the ECG and cardio biomarker criteria for acute MI were included in study. Patients with malignancy, renovascular disease, pregnancy, DVT, sepsis and those who are using drugs altering plasma fibrinogen levels like rosiglitazone, were excluded from the study.

Rapid turbidimetric method was adopted for estimation of fibrinogen level. Heparinized plasma of the patients $(0.2 \mathrm{ml})$ was washed with $3-8 \mathrm{ml}$ of freshly prepared $12.5 \%$ sodium sulfide solution. Shaken well and allowed to stand for 10 minutes. It was shaken again and the turbidity 
noted. Turbidity of protein standards was also for control group also determined. measured for comparison. Plasma fibrinogen level

\section{Observations / Results}

Table no. 1- Risk factors in study and control populations

\begin{tabular}{|l|c|c|c|c|c|c|}
\hline \multirow{2}{*}{ Risk factors } & \multicolumn{2}{|c|}{$\begin{array}{c}\text { No. of patients in } \\
\text { control population }\end{array}$} & \multicolumn{2}{c|}{$\begin{array}{c}\text { No. of patients in } \\
\text { study population }\end{array}$} & t value & $\begin{array}{c}\mathrm{p} \\
\text { value }\end{array}$ \\
\cline { 2 - 6 } & No. & $\%$ & No. & $\%$ & & \\
\hline Diabetes mellitus & 0 & 0 & 24 & 48 & 2.82 & $<0.01$ \\
\hline Hypertension & 2 & 20 & 29 & 58 & 2.19 & $<0.05$ \\
\hline Smoking & 1 & 10 & 26 & 52 & 2.44 & $<0.05$ \\
\hline Obesity & 1 & 10 & 23 & 46 & 2.12 & $<0.05$ \\
\hline Dyslipidemia & 1 & 10 & 26 & 52 & 2.44 & $<0.05$ \\
\hline
\end{tabular}

Out of total 128 patients of study population, Diabetes mellitus was observed in $48 \%$, Hypertension in 58\%.smoking in $52 \%$, hyperlipidemia in $52 \%$ and obesity in $46 \%$ as mentioned in above table ${ }^{[4]}$. It was observed that
Diabetes Mellitus was having significant correlation with acute MI patients ( $p$ value $<0.01$ ) whereas other risk factors were not statistically significant. ${ }^{[9]}$

Table no. 2 Levels of highly sensitive plasma fibrinogen level

\begin{tabular}{|l|c|c|}
\hline & $\begin{array}{c}\text { Mean plasma fibrinogen levels } \\
(\mathrm{mg} / \mathrm{l})\end{array}$ & Standard deviation \\
\hline Study group & 382.8 & 55.36 \\
\hline Control group & 304.3 & 68.72 \\
\hline
\end{tabular}

The mean plasma fibrinogen levels seen in the study group was $382.8 \pm 55.36$ whereas in the control group it was $304.3 \pm 68.72$. There was a significant difference in the mean plasma fibrinogen values of the study and the control populations which was statistically significant $(\mathrm{t}=3.39$, $\mathrm{p}$ value $<0.001)$.

Table no. 3 Plasma fibrinogen level in various risk groups of the study sample

\begin{tabular}{|l|c|c|c|}
\hline & $\begin{array}{c}\text { Total no. of } \\
\text { patients }\end{array}$ & $\begin{array}{c}\text { Patients with high plasma } \\
\text { fibrinogen level }\end{array}$ & Percentage \\
\hline Diabetes & 24 & 20 & $83.33 \%$ \\
\hline Hypertension & 29 & 23 & $79.31 \%$ \\
\hline Smoking & 26 & 21 & $80.76 \%$ \\
\hline Obesity & 23 & 20 & $86.95 \%$ \\
\hline Dyslipidemia & 26 & 23 & $88.46 \%$ \\
\hline
\end{tabular}

As shown in above table, out of a total of 128 patients, high plasma fibrinogen values (>382.8 $\mathrm{mg} / \mathrm{L}$ ) were seen in $60 \%$ of study population at the time of admission. ${ }^{[10]}$ On comparing plasma fibrinogen to conventional risk factors, high levels (>382.8 mg/dL) were seen in $83.33 \%$ diabetics,
$79.31 \%$ hypertensives, $88.46 \%$ hyperlipidemics, $80.76 \%$ of smokers, $86.95 \%$ of obese patients at the time of admission. Highest or maximum significant correlation was found between hyperlipidemia and high plasma fibrinogen levels in patients of acute coronary syndrome. 
Table no. 4 Association of clinical complications with plasma fibrinogen level in study population

\begin{tabular}{|c|c|c|c|c|}
\hline & $\begin{array}{c}\text { Patients with } \\
\text { arrhythmias }\end{array}$ & $\begin{array}{c}\text { Patients without } \\
\text { arrhythmias }\end{array}$ & T value & P value \\
\hline $\begin{array}{l}\text { Mean plasma } \\
\text { fibrinogen level }\end{array}$ & $407 \pm 45.82$ & $358.3 \pm 53.91$ & 3.47 & 0.001 \\
\hline $\begin{array}{l}\text { Mean plasma } \\
\text { fibrinogen level }\end{array}$ & Patients with shock & Patients without shock & T value & P value \\
\hline plasma & $403.42 \pm 47.8$ & $367.93 \pm 56.38$ & 2.42 & 0.02 \\
\hline $\begin{array}{l}\text { Mean CHF } \\
\text { fibrinogen level }\end{array}$ & Expired & No CHF & T value & P value \\
\hline & Not expired & 2.72 & 0.0005 \\
\hline $\begin{array}{l}\text { Mean plasma } \\
\text { fibrinogen level }\end{array}$ & $411.09 \pm 30.51$ & $362.379 \pm 60.55$ & 2.35 & 0.02 \\
\hline
\end{tabular}

There was a significant difference in the mean plasma fibrinogen of patients who developed complications such as arrhythmias $407 \pm 45.82(\mathrm{t}$ value $=3.47, \mathrm{p}$ value $=0.001)$, shock $403.42 \pm 47.8$ (t value $=2.42, \mathrm{p}$ value $=0.02), \mathrm{CHF} 403.42 \pm 38.88$ $(\mathrm{t}$ value $=3.72, \mathrm{p}$ value $=0.0005)$ and death $411.09 \pm 30.51$ ( $\mathrm{t}$ value $=2.35$, $\mathrm{p}$ value $=0.02)$, as compared to those who did not. Overall the elevated fibrinogen levels observed in patients developing complications were found to be statistically significant.

\section{Discussion}

The physiological importance of elevated plasma fibrinogen levels is not fully understood. The mechanism by which plasma fibrinogen may be involved in atherothrombosis are theological alterations, increased platelet aggregation tendency, increased fibrin formation and the stimulation of vascular cell proliferation and migration with increasing plasma fibrinogen levels. $^{[12]}$

Elevated fibrinogen concentrations could be due to the disease (i.e. MI) or to an underlying vascular disease (e.g. atherosclerosis) rather than as a cause of MI or vascular disease ${ }^{[13]}$. It is possible that because serum has often been stored for a considerable period of time, the measurement of serum levels of fibrinogen may be compromised. ${ }^{[16]}$

In our study, the mean plasma fibrinogen levels seen in the patient group $382.8 \pm 55.36$ whereas in the control group mean plasma fibrinogen level values were $304.3 \pm 68.72$, which was statistically significant $(\mathrm{t}=3.39, \mathrm{p}$ value $<0.001)$. In these patients, not only high plasma fibrinogen levels seen in acute MI patients but also with other conventional risk factors in our study. High fibrinogen level has also high mortality and morbidity ${ }^{[14]}$.In our study complications such as CHF, arrhythmias and cardiogenic shock correlated very well with high fibrinogen values. Incidence of complications with levels of high plasma fibrinogen $(>382.8 \mathrm{mg} / \mathrm{dl} \quad$ vs $\quad<382.8$ $\mathrm{mg} / \mathrm{dl}$ ) was statistically significant. The mean plasma fibrinogen level in the mortality group was $403.94+38.88$ which was more than the overall mean plasma fibrinogen of $382.8 \pm 55.36$ in the study population.

These findings are similar to previous studies which have found high levels of plasmafibrinogen to be a reliable predictable marker of mortality in patients of acute MI and provides important weight to the aggregate evidence regarding this biomarker for risk assessment in ACS.

Similar findings were observed different related studies. A study by Zhang Y et al in 2014 has indicated that higher fibrinogen level is positively and independently associated with the presence and severity of new-onset coronary atherosclerosis and observed that the value of plasma fibrinogen $>3.21 \mathrm{~g} / \mathrm{L}$ suggested a more severe coronary stenosis ${ }^{[15]}$. Similarly study conducted by Song et al in 2015 found plasma fibrinogen levels of patients were 0.94-folder higher than control group, and showed a significantly association between plasma fibrinogen level and CHD risk $(\mathrm{P}<0.0001) .{ }^{[18]}$ 


\section{Conclusion}

The present epidemic of CAD in north Indian patients can't be explained with conventional risk factors. Search for newer non-conventional risk factors like plasma fibrinogen, $\mathrm{C}$ reactive protein $^{[19]}$, homocysteine in north Indian population are necessary to explain the present epidemic. ${ }^{[20]}$

In our study we concluded that plasma fibrinogen may be a ray of light to predict the evolving CAD, prevention, to predict prognosis in future. But the sample size was small and we had financial as well as resource limitations .A larger study with more number of cases is required to further confirm our findings. Similar results were observed by Yemell et al, 1983 in caerphilly speedwell area who also concluded that there is strong association between plasma fibrinogen level and CAD. ${ }^{[16]}$

\section{Bibliography}

1. Iftikhar J.Kullo and Christie M.Ballantyne. Conditional Risk Factors for Atherosclerosis. Mayo Clinic Proceedings 2005; 80: 219-230.

2. Harish RB, Govindaraju V, Manjunath CN. Risk prediction-Homocysteine in Coronary Heart Disease. Indian J Clin Biochem. 2007 Mar;22(1):18-21.

3. Knopp RH. Risk factors for coronary artery disease inwomen. Am J Cariol 2002; 89 (S12A): 28E-34E.

4. Assmann G, Cullen $P$ and Schulte H. Simple scoring calculating the risk of acute coronary events based on 10 year follow-up of the Prospective Cardiovascular Munter (PROCAM) study. Circulation 2002; 105: 310-315.

5. Binder $\mathrm{CJ}$, et al: Innate and acquired immunity in atherogenesis. Nat. Med.2002; 8: 12118.

6. M. Loukas, M. Dabrowski, T. Wagner, E. Walczak, A. Witkowski, and W. Ruzyłło, "Fibrinogen and smooth muscle cell detection in atherosclerotic plaques from stable and unstable angina -an immunohistochemical study," Medical Science Monitor, vol. 8, no. 4, pp. BR144BR148, 2002

7. Ndrepepa G, Braun S, King L, Fusaro M, Keta D, Cassese S, Tada T, Schömig A, Kastrati A. Relation of fibrinogen level with cardiovascular events in patients with coronary artery disease. Am J Cardiol. 2013 Mar 15;111(6):804-10.

8. Pearson TA, Menash GA, Alexender RW, et al: Markers of inflammation and cardiovascular disease: application to clinical and public health practice: Circulation. 2003; 107: 499-511.

9. Peter Libby, Paul M.Ridker, Attilio Maseri: Inflammation and Atherosclerosis: Circulation. 2002; 105: 1135.

10. Mohan, V., Deepa, R., Shanthirani, S. and Premalatha, G., J. Am. Coll. Cardiol., 2001, 38, 682-687.

11. Khaw, K. T., Wareham, N., Luben, R., Bingham, S., Oakes, S., Welch, A. and Day, N., Br. Med, J., 2001, 322, 15-18.

12. Ernst E. The role of fibrinogen as a cardipovascular risk factor. Atherosclerosis. 1993; 100:1-12.

13. Mach $\mathrm{F}$ et al: C-reactive protein as a marker for acute coronary syndrome. Eur. Heart J. 1997 Dec; 18(12) : 1897-902.

14. Gao XY, Zhou BY, Zhang MZ, et al. Association between fibrinogen level and the severity of coronary stenosis in 418 male patients with myocardial infarction younger than 35 years old. Oncotarget. 2017;8(46):81361-81368. Published 2017 Jun 20. doi:10.18632/oncotarget.18578

15. Zhang Y, Zhu CG, Guo YL, Xu RX, LiS, Dong Q, Li JJ. Higher fibrinogen level is independently linked with the presence and severity of new-onset coronary atherosclerosis among Han Chinese population. PLoS One. 2014 Nov 26;9(11)

16. Papageorgiou N, Briasoulis A, Hatzis G, Androulakis E, Kozanitou M, Miliou A, 
Charakida M, Zacharia E, Papaioannou S, Paroutoglou I, Siasos G, Pallantza Z, Tousoulis D ,Coronary Artery Atherosclerosis in Hypertensive Patients: The Role of Fibrinogen Genetic Variability. Rev Esp Cardiol (Engl Ed). 2017 Jan;70(1):34-4.

17. Ernst E. The role of fibrinogen as a cardiovascular risk factor. Atherosclerosis. 1993 Apr;100(1):1-12

18. Song B, Shu Y, Xu YN, Fu P. Plasma fibrinogen lever and risk of coronary heartdisease among Chinese population: a systematic review and meta-analysis. Int J Clin Exp Med. 2015 Aug 15;8(8):13195202.

19. Li T, Wang F, Peng R, Pei S, Hou Z, Lu $\mathrm{B}$, Cong $\mathrm{X}$, Chen $\mathrm{X}$. Sex-related differences in the association between plasma fibrinogen and non-calcified or mixed coronary atherosclerotic plaques. Biol Sex Differ. 2018 Dec 5;9(1):51

20. Montalescot G, Ankri A, Vicaut E, Drobinski G, Grosgogeat Y, Thomas D. Fibrinogen after coronary angioplasty as a risk factor for restenosis. Circulation. 1995 Jul 1;92(1):31-8.

21. Boda Z. Fibrinogen as an independent cardiovascular risk factor and the question of treatment with fibrinogen-lowering drugs. Orv Hetil. 1997 Sep 28;138(39): 2455-60. Review. 